\title{
Environmental Effect of Reservoirs Accumulating Highly Mineralized Oil-Field Waste Waters
}

\author{
Ilyusya M. Gabbasova, Ruslan R. Suleymanov \\ Laboratory of Soil Science, Institute of Biology, Ufa Research Centre, Russian Academy of Sciences, Ufa, Russia \\ E-mail:soils@mail.ru \\ Received December 1, 2009; revised January 19, 2010; accepted February 8, 2010
}

\begin{abstract}
The effect of oilfield waste water on the ground, the soil and the underground water has been studied. The reservoir is shown to be the source of environmental pollution due to the seepage of highly mineralized waste water through the reservoir bed and walls. Increased water mineralization in the spring two kilometers downward from the reservoir is one indication of it. Desalinization of the water should be expected in 140 years' time. Typical chernozem formed on the area under study 40 years after the contamination have become naturally desalinized and desolonized as a result of a washing water regime and a genetically high content of carbonates and gypsum in the profile and soil forming rocks. Moreover, they retain an increased content of water-soluble salts, exchangeable sodium and electrical resistance, which is typical for alkali soils and solonetzs. The humus accumulative horizons show hydrophobic behavior. Due to leaching carbonates content, cation exchange capacity, mobile nitrogen and phosphorus availability decrease. Soil contamination by OWW leads to the accumulation of toxic elements in the soil and vegetation.
\end{abstract}

Keywords: Oilfield Waste Water, Salinization, Toxic Elements, Ground Waters, Soil Properties

\section{Introduction}

As is known, oil is extracted together with concomitant water and natural gases. Oilfield waste water (OWW) is made of brine water and process water. Brine underground water which is extracted together with oil makes up 80$90 \%$ of total waste volume, hence, it defines oilfield waste water properties [1]. Water in oil-bearing beds has some specific properties relevant to ecology. First of all, it is high mineralization, prevailing $\mathrm{Cl}^{-}$ions in anions and $\mathrm{Na}^{+}$ ions in cations. Besides, OWW is a multi-ingredient pollutant with a high geochemical activity and toxicity [2].

It is gas condensate, diethyleneglycol, mineral soluble compounds and mechanical impurities that normally prevail in this water. The content of technogenic hydrocarbons may be as high as $260 \mathrm{mg} / \mathrm{L}$. Organogenic horizons are mostly affected by salts. The penetrating speed and depth of OWW is considerable. Solntseva [3] indicated that a soil adsorbent complex (in cation content) does not revert to its initial state until 20-25 years later, and the degradation may become irreversible. OWW contamination affects both enzymatic and microbiological soil activity. According to [4], in the degree of inhibition, enzymes of polluted typical chernozem can be de- creasingly ranged as follows: urease - invertase - phosphotase - dehydrogenase - catalase.

Sodium chloride salinization, characteristic for OWW contaminated soils, had a negative impact on the dynamics of permanent grass biomass [5], on the growth and yield of some rice sorts [6], and contributed to the deterioration of gaseous exchange in Salix viminalis L. [7].

OWW contains different toxic microelements, mostly heavy metals and radioactive elements. N. S. Minigazimov [8] claimed that the content of $\mathrm{Zn}, \mathrm{Fe}, \mathrm{Hg}, \mathrm{Ba}, \mathrm{Br}$, B, $\mathrm{I}, \mathrm{Sr}, \mathrm{Li}, \mathrm{Pb}, \mathrm{Cu}, \mathrm{Ag}, \mathrm{Ti}, \mathrm{U}$ and others may exceed maximum concentration indices.

The above facts are clear evidence of negative effects of OWW contamination on the environment and human health.

The aim of this investigation was the study of the impact of an OWW accumulating reservoir on the rocks, the underground water and the soil, as well as the state they come to in 40 years after the contamination.

The following meanings were to be solved in the course of the study: to determine the time required for the ground water desalinization; to study physical and chemical properties of the soil and the content of toxic elements in the soil and vegetation. 


\section{Methods}

In the process of oilfield operation (specifically at the stage of field development), it is often necessary to collect waste water in the so-called technical storage reservoirs, which may eventually become a source of contamination to fresh underground water, ground and soil.

The field research was done on the area of the Shkapovski oilfield, in the valley of the Bazlik river, where a storage reservoir was built in 1960-1961. At the bottom and left wall of the valley deluvial and periglacial clays and loam soils are as thick as $10 \mathrm{~m}$. Brine water with mineralization of $270 \mathrm{~g} / \mathrm{L}$ was released throughout $1962-$ 1966 [9].

The ground samples were taken from drilled wells in five replications. The underground water was taken from natural sources and regime wells. Soil profiles were made on contaminated plots 40 years after the reservoir had been abandoned. Figure 1 schematically shows the location of the abandoned reservoir, the Bazlik river, the spring, and the plots where the soil was sampled. Analytical tests have been made with the use of standard techniques [10]. The material has been processed using conventional methods of mathematical statistics. Elemental soil and vegetation composition has been determined using the mass-spectrometric method with inductively coupled plasma-ICP-MS, PLASMA-QUAD, VG instruments company. The equation of well water desalinization dependence on the years has been derived via the approximation of experimental data to a power function. All mathematical calculations and graph constructions have been performed using Microsoft Office Excel 2003. Materials have been treated using methods of mathematical statistics.

\section{Results and Discussion}

When the reservoir was being constructed the clay shield was hoped to be a reliable isolation and the release was expected to be insignificant in view of its poor filtration properties. But in the very first year of operation (summer 1963), gryphons of salt water appeared below the dam, and the sources previously used for water supply became salinized (the village of Bazlik, $2 \mathrm{~km}$ downward from the reservoir). As a consequence, the reservoir was abandoned.

5-6 years after the discontinuation of salt water release the salt content in the bottom clay made up 2000-2500 $\mathrm{mg} / 100 \mathrm{~g}$ (1200-1500 mg/100g of chlorine). Mineralization of water extraction from non-salinized clay (from the valley walls) made up 40-70 $\mathrm{mg} / 100 \mathrm{~g}$ (chlorine 1.8 $3.6 \mathrm{mg} / 100 \mathrm{~g}$ ), the composition being hydrocarbonate sodium-calcium.

Another examination of the grounds in the reservoir bed made 19 years after its abandonment (1984) revealed considerable desalinization of the clay under the first super floodplain terrace and the bed as a result of annual spring tide. The overall salt content lowered to 70-90 $\mathrm{mg} / 100 \mathrm{~g}$, the chorine content to $3-10 \mathrm{mg} / 100 \mathrm{~g}$ [11].

In order to find further changes in the water-salt regime of clay and its exchange-adsorptive properties, another series of investigations was done in July 1991 and August 1997. Sampling was done ibid. The results showed further rock desalinization in the reservoir bowl. The chlorine ion content under the bed did not exceed 3-7 mg/100g, which is close to its content under natural conditions (3-5 $\mathrm{mg} / 100 \mathrm{~g}$ ). The salt concentration fell to $370-620 \mathrm{mg} / 100 \mathrm{~g}$ on the second over flood land as well (chlorine to 200$380 \mathrm{mg} / 100 \mathrm{~g}$ ).

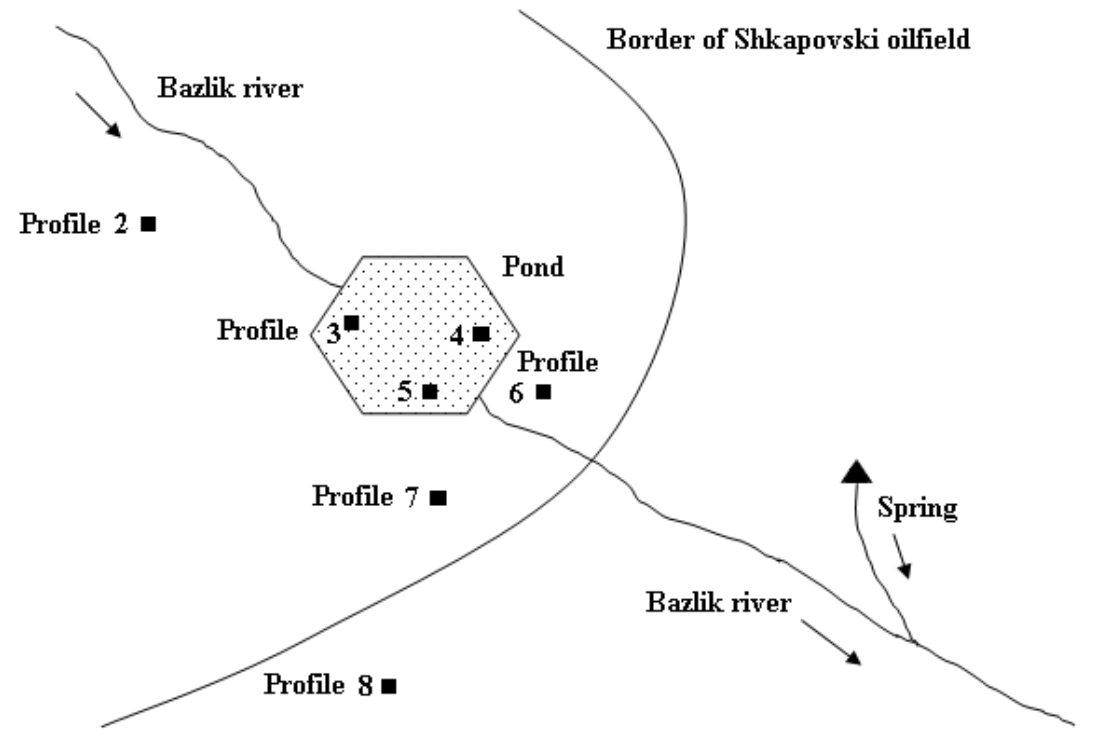

Figure 1. Location of the abandoned reservoir, the spring and soil sampling plots. 
In spring, the water head in the pond reached 3-5 m, increasing under bed filtration. By mid-summer only small lakes of fresh water $(310 \mathrm{mg} / \mathrm{L})$, with $2-3 \mathrm{~cm}$ of oil surface, persisted.

Qualitative changes occurred in the composition of absorbed complex (AC) of clay rock. Upon waste release discontinuation, the clay foundation became solonized as a result of the cation exchange with oil brines; sodium concentration reached $10-53.5 \%$ of the rock cation exchange capacity, whereas outside the impact it was no higher than $2-4 \%$.

It is worth mentioning that a relatively short-time (2-3 years) influence of oilfield brines on the clay foundation followed by a continuous washing with low-mineralized atmospheric precipitate (38 years) considerably altered both the salt and the absorbed cation composition. Bivalent cations (76-91\% of calcium, $19.5-40 \%$ of magnesium) became prevalent again. Sodium and potassium concentration was $1.3-4.5 \%$. An increased content (to 9.0-12.5\%) of univalent cations persisted in the chloride salt saturated cuts. Cation exchange capacity (CEC) of clay in an intensively washed part of the lake remained as low as 16.27-19.69 mg-equ/100g and 6.68-14.69 $\mathrm{mg}$-equ $/ 100 \mathrm{~g}$. On the terrace, in the absence of salinization and following washing, AC capacity value was considerably higher (28.0-45.3 mg-equ/100g).

With a general reduction in the salt concentration, the maximum chlorine concentration was $371 \mathrm{mg} / 100 \mathrm{~g}$. It should also be underlined that, over the observation period, the oil products content did not notably decrease.

The scale and character of fresh water contamination as well as the duration of contaminants effect depend on many factors, such as: A geological composition (rock lithology), mobility of water in the upper hydrodynamic zone, sort and composition of a contaminant, an oilfield operation time, etc. The area of salinized fresh water at the oilfield under study amounts to $5000 \mathrm{~km}^{2}$.

The analysis of a chemical composition and mineralization of the underground water samples revealed its variability with years. Mineralization within the oilfield area was gradually going down. Mineralization level often depended on the spring output: the output decrease was accompanied by an increased concentration of diluted salts and vice versa. The spring output change is accounted for by the amount of precipitation, otherwise stated, an interrelation can be observed between water chemistry, spring output and hydro-meteorological factors, suggesting penetration of oil brines into fresh water horizons by means of a convective-filtration way, mainly through the aeration zone.

Figure 2 shows the level of water mineralization in the spring located $10 \mathrm{~km}$ from the reservoir. It can be seen that the curve of water mineralization dependence on the number of years after the contamination is an exponent, and can be described by the equation $\mathrm{y}=$ $10.027 \mathrm{e}^{-0.0599 \mathrm{x}}, \mathrm{R}^{2}=0.9279, \mathrm{P}>0.95$. The curve indicates that in the first 20 years mineralization changes in the range of $12000-5000 \mathrm{mg} / \mathrm{L}$ and is uneven over the years, in the following years it decreases more gradually and consistently. The fluctuations in the level of water mineralization with a high content of salts in the first years may be more dependent on the annual precipitation. With concentrations below $5000 \mathrm{mg} / \mathrm{L}$, mineralization level goes down gradually and is not greatly dependent on annual precipitation.

In the springs outside the reservoir impact, water mineralization makes up 5-7 mg/L. Inserting $\mathrm{y}=5 \mathrm{mg} / \mathrm{L}$ into the equation, we can get $\mathrm{x}$ - the number of years necessary for complete desalinization of the water.

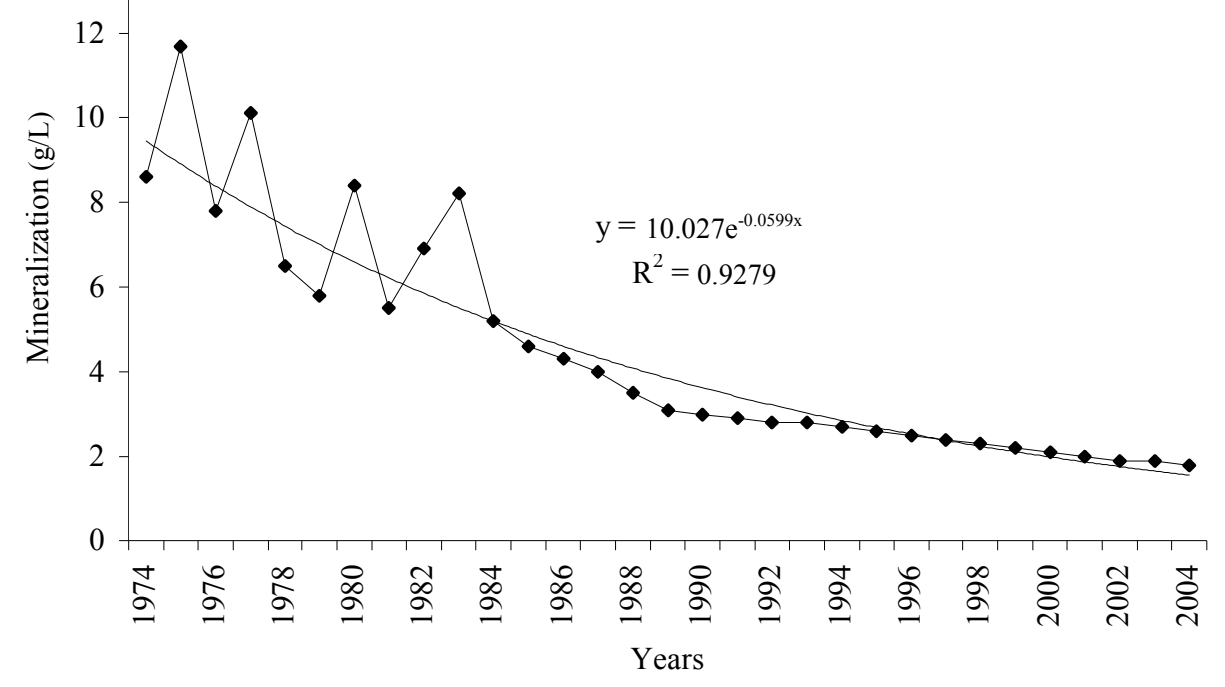

Figure 2. Dynamics of water mineralization in the spring $2 \mathrm{~km}$ away from the reservoir. 
1) $y=a \cdot e^{-k x}$

2) $e^{-k x}=y \cdot a^{-1}$

3) $\ln \left(a \cdot y^{-1}\right)=k \cdot x$

4) $x=k^{-1} \cdot \ln \left(a \cdot y^{-1}\right)$

with $\mathrm{k}=0.0599, \mathrm{a}=10.027, \mathrm{y}=0.005$, we have $\mathrm{x}=126$.

Desalinization of ground water can be expected in 126 years from the observation starting time to 1974. But the reservoir was abandoned in 1960-1961-14 years prior to the observations, and, in the course of those years, desalinization could be well under way. So, it can be inferred that ground water desalinization is to take no less than 140 years after the reservoir abandonment. The forecast is in good agreement with the previously obtained data [9] concerning the necessity of a triple water cycle in soil and clay sediments for desalinization.
The soil cover around the reservoir is typical carbonate chernozem. The soil in the profile cuts $1 \mathrm{~km}$ up and down the reservoir escaped OWW contamination. It has the following characteristics: a high humus content, high CEC, $0.4 \%$ to $0.65 \%$ carbonates, neutral reaction. The supply of available nitrogen and phosphorus is high (Table 1).

The reservoir creation resulted in the disturbance of the cover in both the bottom and the adjacent soil. It is an evident fact that the soil was salinized and solonized. In 40 years' time after the reservoir abandonment, the level of residual salinization did not exceed $0.1 \%$, which is the sign of complete natural desalinization of the soil. The content of exchangeable sodium in the profile cut varies in the range of $0.7-3.5 \%$ of $\mathrm{CEC}$, suggesting the absence of solonization. Moreover, compared to the controls (cuts 7 and 8), they contain 3 times as much water soluble salts

Table 1. Physical and chemical properties of soils.

\begin{tabular}{|c|c|c|c|c|c|c|c|c|c|c|}
\hline \multirow{3}{*}{$\begin{array}{c}\text { Soil } \\
\text { horizons, } \\
\text { depth, } \mathbf{c m}\end{array}$} & \multirow{3}{*}{$\begin{array}{c}\mathbf{p H} \\
\mathbf{H}_{2} \mathrm{O}\end{array}$} & \multirow{3}{*}{$\begin{array}{c}\text { Dry } \\
\text { matter }\end{array}$} & \multirow{2}{*}{$\begin{array}{c}\text { Humus } \\
\text { total }\end{array}$} & \multirow{2}{*}{$\begin{array}{c}\text { Carbonates, } \\
\mathrm{CO}_{2}\end{array}$} & \multirow{2}{*}{$\begin{array}{c}\text { Water soluble } \\
\text { Na }\end{array}$} & \multirow{2}{*}{$\begin{array}{c}\text { Na } \\
\text { exch. }\end{array}$} & \multirow{2}{*}{ CEC } & \multirow{2}{*}{$\begin{array}{l}\text { N alkali- } \\
\text { hydrated }\end{array}$} & \multicolumn{2}{|c|}{$\mathbf{P}_{2} \mathbf{O}_{5}$} \\
\hline & & & & & & & & & total & available \\
\hline & & & \multicolumn{2}{|c|}{$\%$} & \multicolumn{3}{|c|}{ mg-equ/100g } & $\mathbf{m g} / \mathbf{k g}$ & \multicolumn{2}{|c|}{$\mathbf{m g} / 100 \mathrm{~g}$} \\
\hline \multicolumn{11}{|c|}{ Profile 2-2004 Chernozem typical polluted by OWW } \\
\hline A10-28cm & 6.85 & 0.09 & 10.80 & 0.036 & 0.1 & 0.40 & 34.82 & 124 & 191.2 & 2.14 \\
\hline $\mathrm{AB} 28-52 \mathrm{~cm}$ & 6.40 & 0.12 & 6.19 & 0.072 & 0.1 & 0.40 & 31.93 & 66 & 125.4 & 0.52 \\
\hline B52-90 cm & 6.40 & 0.08 & 2.81 & 0.108 & 0.15 & 0.65 & 33.67 & 56 & 56.4 & 0.14 \\
\hline \multicolumn{11}{|c|}{ Profile 3-2004 Chernozem typical polluted by OWW } \\
\hline $\mathrm{A} 10-40 \mathrm{~cm}$ & 7.20 & 0.08 & 10.22 & 0.072 & 0.1 & 0.25 & 34.96 & 124 & 188.1 & 1.00 \\
\hline B40-80 cm & 7.10 & 0.07 & 2.65 & 0.072 & 0.15 & 0.35 & 24.60 & 42 & 56.4 & 0.48 \\
\hline \multicolumn{11}{|c|}{ Profile 4-2004 Degradated soil } \\
\hline A $10-40 \mathrm{~cm}$ & 7.65 & 0.09 & 6.63 & 0.108 & 0.1 & 0.3 & 26.62 & 140 & 131.6 & 0.57 \\
\hline \multicolumn{11}{|c|}{ Profile 5-2004 Degradated soil } \\
\hline A $10-40 \mathrm{~cm}$ & 7.85 & 0.11 & 7.45 & 0.072 & 0.25 & 0.85 & 24.63 & 98 & 97.18 & 2.38 \\
\hline \multicolumn{11}{|c|}{ Profile 6-2004 Degradated soil } \\
\hline A $10-44 \mathrm{~cm}$ & 8.40 & 0.13 & 6.20 & 0.036 & 0.15 & 0.35 & 32.50 & 182 & 116.0 & 1.52 \\
\hline B62-96 cm & 9.10 & 0.09 & 1.98 & 0.072 & 0.2 & 0.5 & 19.43 & 84 & 69.0 & 2.52 \\
\hline C96-120 & 9.40 & 0.09 & 0.68 & 11.276 & 0.15 & 0.3 & 6.52 & 56 & 128.5 & 9.96 \\
\hline \multicolumn{11}{|c|}{ Profile 7-2004 Chernozem typical carbonated } \\
\hline A10-26 cm & 7.50 & 0.03 & 11.02 & 0.361 & 0.15 & 0.35 & 44.61 & 238 & 172.4 & 14.1 \\
\hline $\mathrm{AB} 46-67 \mathrm{~cm}$ & 7.40 & 0.08 & 4.17 & 0.452 & 0.15 & 0.35 & 35.48 & 98 & 100.3 & 1.9 \\
\hline B67-96 cm & 7.70 & 0.09 & 3.30 & 0.452 & 0.15 & 0.35 & 33.67 & 56 & 94.0 & 2.38 \\
\hline \multicolumn{11}{|c|}{ Profile 8-2004 Chernozem typical carbonated } \\
\hline $\mathrm{A} 10-28 \mathrm{~cm}$ & 7.10 & 0.05 & 9.63 & 0.398 & 0.15 & 0.2 & 46.21 & 238 & 188.1 & 12.48 \\
\hline $\mathrm{AB} 42-70 \mathrm{~cm}$ & 7.05 & 0.07 & 4.50 & 0.361 & 0.15 & 0.2 & 34.66 & 84 & 78.4 & 1.67 \\
\hline B70-100 cm & 7.35 & 0.08 & 2.10 & 0.651 & 0.15 & 0.2 & 26.99 & 42 & 72.1 & 2.14 \\
\hline $\begin{array}{l}\text { A1 - humus a } \\
\text { AB - transitio } \\
\text { B - illuvial ho } \\
\text { C - parent roc }\end{array}$ & $\begin{array}{l}\text { mulat } \\
\text { horiz } \\
\text { on }\end{array}$ & torizon & & & & & & & & \\
\hline
\end{tabular}


and exchangeable sodium, whereas in the lower part of the profile, the content of exchangeable sodium is close to a threshold value $5 \%$ of CEC. The values of resistivity in the range of 100-300 $\Omega \cdot \mathrm{m}$ confirm this fact, their values in non-contaminated soil being higher than $600 \Omega \cdot \mathrm{m}$.

OWW contamination promoted leaching of free carbonates, whose content is about tenfold lower than in the control carbonate typical chernozem. This led to some acidation in the soil (cut 2) which was unmixed with lower illuvial horizons. Despite the reduction in the amount of free carbonates, the degraded soil in the reservoir bed became alkalized. The alkalization level reached 9.1 $\mathrm{pH}$ in the illuvial horizon (62-96 cm deep), obviously, as a result of residual solonization.

The content of total humus in the upper horizons of contaminated soil approaches the control, whereas in the degraded soil it is noticeably lower and reduces more dramatically down the profile. The humus accumulative soil horizons under the effect of OWW are characterized by high hydrophobity of structural aggregates, considerably deteriorating the soil water and nutrient regime, all the more so that the content of mobile phosphorus is 6-15 fold less. Also, nitrogen availability in the polluted soil is somewhat lower than in the control, whereas in the mixed soil it is 2-3 times lower. The content of total phosphorus alters similarly to soda hydrolyzable nitrogen.

On some parts of the abandoned reservoir bed, the surface is severely mazutized; the vegetation is absent; in the depressions, water is surfaced with oil films.

OWW contamination leads to the accumulation of toxic elements on the area by far exceeding the area of immediate impact. Cd, As, Zn, Mo, Cu, Co, Ni, Cr, Sr, V (elements of 1-3 toxicity classes) accumulate in the amounts higher than the maximum concentration limit and control values.

The plants on the contaminated area accumulated toxic elements. Strawberry (Fragaria viridis (Duch) Weston) leaves showed an increased level of $\mathrm{Pb}, \mathrm{Sr}, \mathrm{V}, \mathrm{Rb}, \mathrm{Ba}$; yarrow (Achillea millefolium L.) leaves- $\mathrm{Cd}, \mathrm{Rb}, \mathrm{Ba}$.

\section{Conclusions}

The OWW accumulating reservoir on the area of Shkapovski oil field has become the source of contamination of the rock, the ground water and the soil, as a result of highly mineralized waste water seepage through the bed and walls.

After the contamination, water mineralization in the spring $2 \mathrm{~km}$ downward the reservoir increased from 5-7 $\mathrm{mg} / \mathrm{L}$ to $12 \mathrm{mg} / \mathrm{L}$, and 30 years later (in 2004) it was 2 $\mathrm{mg} / \mathrm{L}$. The dependence of mineralization on the number of years post the contamination is of an exponential character, and it can be expressed by the equation $\mathrm{y}=$ $10.027 \mathrm{e}^{-0.0599 \mathrm{x}}(\mathrm{P}>0.95)$, from where it can be inferred that ground water should be fully desalinized 140 years after contamination.

40 years after the OWW contamination, soils naturally desalinize and desolonize but, at the same time, they have an elevated content of water soluble salts, exchangeable sodium and resistivity inherent to salinized soils. Leaching causes a reduced content of carbonates and cation exchange capacity. Water and nutrient regimes deteriorate; mazutization persists.

The contamination also shows up in the accumulation of toxic elements in the vegetation and the soils outside the polluted area. Cd, As, $\mathrm{Zn}, \mathrm{Mo}, \mathrm{Cu}, \mathrm{Co}, \mathrm{Ni}, \mathrm{Cr}, \mathrm{Sr}, \mathrm{V}$ (1-3 toxicity classes) have been found in the soil in the concentrations above MPC and background levels. Strawberry (Fragaria viridis (Duch Weston) leaves showed an increased level of $\mathrm{Pb}, \mathrm{Sr}, \mathrm{V}, \mathrm{Rb}, \mathrm{Ba}$; yarrow (Achillea millefolium L.) leaves- $\mathrm{Cd}, \mathrm{Rb}, \mathrm{Ba}$.

\section{References}

[1] M. Z. Gainutdinov, M. Y. Giliazov and I. T. Khramov, "Change in Agrochemical Properties of Alkaline Chernozems under the Impact of Oil-Field Waste Waters and their Remediaton," Agrochemistry, No. 7, 1982, pp. 111116.

[2] N. P. Solntseva and A. P. Sadov, "Influence of Waste Brines on Soils in the Area of Urengoi Oil and Gas Condensate Deposit," Soil Science, Vol. 3, 1997, pp. 322-329.

[3] N. P. Solntseva, "Oil mining and geochemical transformation of landscape," Moscow, 1998.

[4] I. M. Gabbasova, F. K. Khaziev and V. Y. Khakimov, "The Effect of Sewage Water from an Oil Field on the Properties and Biological Activity of Typical Chernozem," Eurasian Soil Science, Vol. 35, No. 1, 2002, pp. 85-90.

[5] P. Baltrenas and A. Kazlauskiene, "Grass Vegetation Dynamics in Soil Contaminated with Salt," Ekologija, Vol. 53, No. 3, 2007, pp. 58-63.

[6] J.-I. Choung, S.-J. Yu, M.-K. Oh, N.-H. Baek, J.-K. Ko and J.-K. Lee, "Varietal Responses of Rice Growth and Yield to Soil Salt Content," Korean Journal Crop Science, Vol. 47, No. 6, 2002, pp. 422-426.

[7] J. Wrobel, M. Mikiciuk and A. Stolarska, "Effect of Salt Soil Stress on Gas Exchange in Three Forms of Basket Willow (Salix viminalis L.)," Ekofizjologiczne Aspekty Reakcji Roslin na Czynniki Stresowe, Warszawa, Vol. 509, 2005, pp. 269-281.

[8] N. S. Minigazimov, "Oil and Heavy Metals (Ecological Aspects)," Bashkir Ecological Bulletin, No. 2, 1999, pp. 24-30.

[9] R. F. Abdrakhmanov, "Technogenesis in Underground Hydrosphere of Pre-Ural," Ufa, 1993

[10] E. V. Arinushkina, "A Guide in Chemical Analysis of Soils," Moscow State University Publishers, Moscow, 1970.

[11] R. F. Abdrakhmanov, "Hydro-ecology of Bashkortostan," Ufa, 2005. 